\title{
Duplex 2209 Weld Overlay by ESSC Process
}

\author{
Er. Manoj Kumar ${ }^{1}$, Dr. Abhishek Kamboj ${ }^{2}$ \\ ${ }^{1}$ M.tech research Scholar,Haryana Engineering College \\ ${ }^{2}$ Associate Professor, Haryana Engineering College
}

\begin{abstract}
In the modern world of industrialization the wear is eating metal assets worth millions of dollars per year. The wear is in the form of corrosion, erosion, abrasion etc. which occur in the process industries like oil \& gas, refineries, cement plants, steel plants, shipping and offshore working structures. The equipments like pressure vessels, heat exchangers, hydro processing reactors which very often work at elevated temperatures face corrosion in the internal diameter. Duplex 2209 weld overlay on ferrous material is developed for high corrosion resistance properties and having high productivity by Electroslag strip cladding process due to its less dilution $\sim 10 \%$ as compared to SMAW , GTAW or FCAW process. Because of Low Dilution $\sim 10 \%$ undiluted chemistry can be achieved with single layer as compared to other weld overlay processes. The facility was developed inhouse to carry out weld overlay by ESSC and Testing.
\end{abstract}

\section{INTRODUCTION}

Duplex stainless steel are called "Duplex" because they have a two-phase microstructure consisting of grains of ferritic and austenitic stainless steel. When duplex stainless steel is melted it solidifies from the liquid phase to completely ferritic structure. As the material cools through temp above about $1040 \mathrm{deg} \mathrm{C}$ to room temperature, about half of the ferritic grains transfer to austenitic grains. The result is a microstructure of roughly $50 \%$ austenite and 50\% ferrite. This is accomplished by increasing Chromium and decreasing $\mathrm{Ni}$ as compared to ASS grades \& by adding Nitrogen (a strong austenite promoter) to speed the rate up of austenite formation during cooling[1].

A minimum $10.5 \%$ Chromium is necessary to form a stable Chromium passive film that is sufficient to protect steel against atmospheric corrosion. The corrosion resistance of SS increases with increasing Chromium content. Chromium is a ferrite former, meaning that the addition of Chromium promotes the BCC structure of iron. At higher Chromium contents, more nickel is necessary to form an austenite or duplex structure. Higher Chromium also promotes the formation of intermetallic phases. Chromium also increases the oxidation resistance at elevated temperatures.

Molybdenum acts to support Chromium in providing pitting corrosion resistance to stainless steels. When the Chromium content of a SS is at least $18 \%$, addition of Mo become about three times as effective as Chromium addition against pitting and crevice corrosion in Chloride-containing environment.Molybdenum is a ferrite former and also increases the tendency of a SS to form detrimental intermetallic phases.Therefore, it is restricted to less than about $7.5 \%$ in ASS and $4 \%$ in Duplex SS[1,2].

Nitrogen increases the pitting and crevice corrosion resistance of austenite and Duplex SS. It also increases strength and is most effective solid solution strengthening element and low cost element. The improved toughness of nitrogen bearing duplex SS is due to their greater austenite content and reduced intermetallic content. Nitrogen does not prevent the precipitation of intermetallic phases but delays the formation of inter- metallics enough to permit processing and fabrication of duplex stainless steel. Nitrogen is added to highly corrosion resistant austenite and duplex stainless steels that contain high chromium and molybdenum contents to offset their tendency to form sigma phase. Nitrogen is the key element, apart from aiding austenite formation, it plays a role in partitioning of alloying element $\mathrm{Cr}, \mathrm{Mo}$ between ferrite and austenite.

During welding, there is a danger that the austenite formed from ferrite from heating, will contain only the low amount of $\mathrm{N}$ that was in the ferrite from which it was formed. if heating time is sufficient ,Nitrogen can diffuse from the original austenite to restore equilibrium.But, if the heating time is too short, the so called secondary austenite will have low $\mathrm{N} \&$ therefore lower pitting corrosion resistance.

Nitrogen helps to alter phase stability, making austenite stable to higher temperature, \& this prevents welds from becoming excessively ferritic and disturbing the desirable 50 to 50 ratio[1,6].

\subsection{Characteristics of Duplex stainless steels \\ $>$ Excellent resistance to stress corrosion cracking}


$>$ Very high mechanical strength

$>$ Excellent resistance to pitting and crevice corrosion

$>$ High resistance to general corrosion in a variety of environments

$>$ Low thermal expansion

$>$ High resistance to erosion corrosion and corrosion fatigue

$>$ Good weldability
$>$ Lower life cycle cost[1]

Duplex stainless steel is having higher critical crevice corrosion temperature as well as critical pitting corrosion temperature as compared to austenitic stainless steel material as shown in below Fig.1 and Duplex stainless steel is having lower corrosion rate than austenitic stainless steel in formic acid Concentration as shown in Fig.2[2,5]

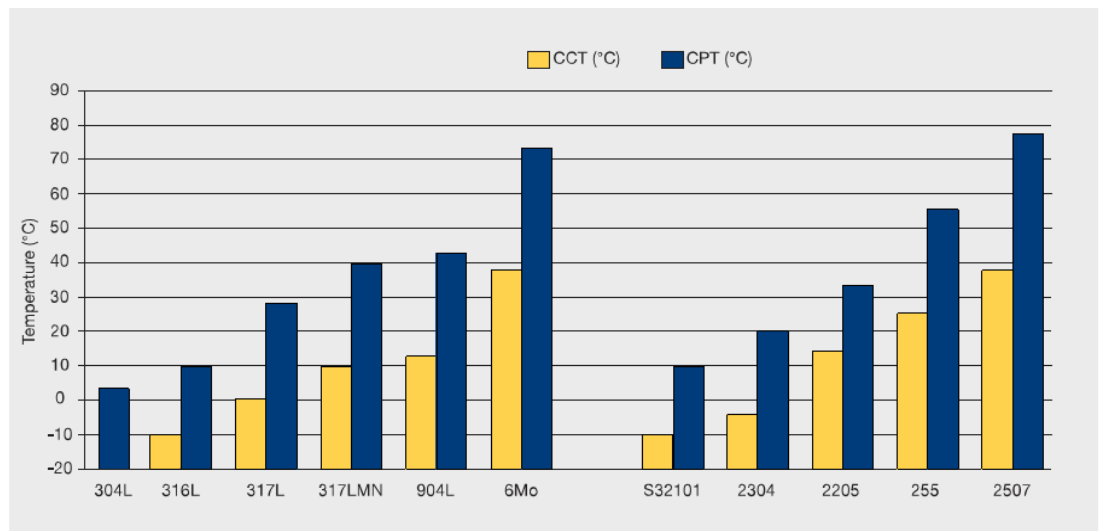

Fig. 1

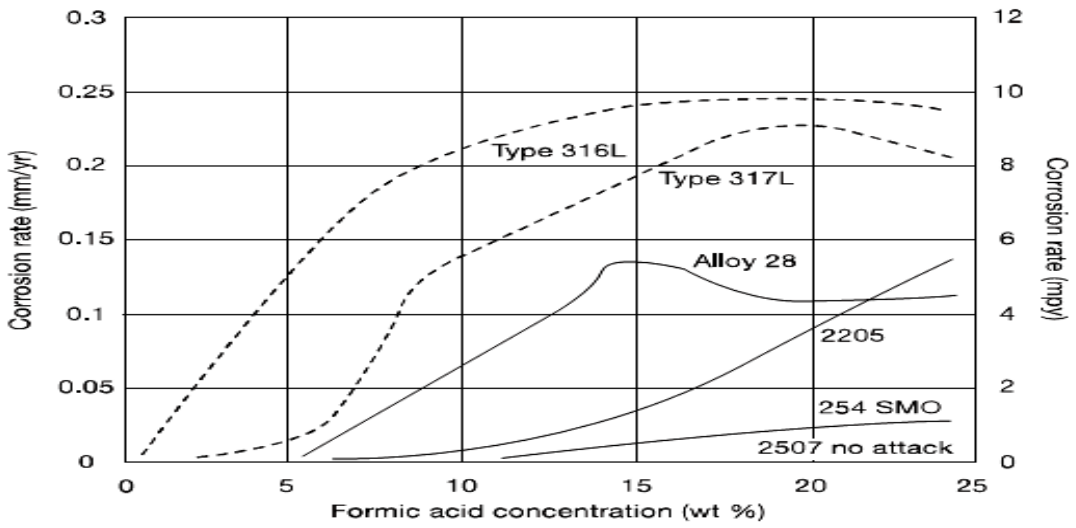

Fig. 2

1.2 Chemical Composition of Dupex 2209

\begin{tabular}{|l|l|}
\hline Element & \% Composition \\
\hline Nickel & $8.5-10.5$ \\
\hline Chromium & $22-24$ \\
\hline Molybdenum & $2.5-3.5$ \\
\hline Carbon & $0.04 \mathrm{max}$ \\
\hline Manganese & $0.5-2.0$ \\
\hline Sulfur & $0.03 \max$ \\
\hline Silicon & $1.0 \max$ \\
\hline Phosphorous & $0.04 \max$ \\
\hline
\end{tabular}

Table 1

Cladding is a welding process in which a material with desired properties is deposited on the surface of a base material. The common $\mathrm{C} / \mathrm{Mn}$ or low alloyed inexpensive base metal has mainly a load carrying function. The deposited sophisticated material imparts surface properties such as corrosion resistance; wear resistance, erosion and pitting etc., to the substrate. To the manufacturer of pressure vessels, surfacing techniques are getting more and more important. Components reach sizes such that their fabrication calls upon the use of clad materials[3,6].

There are different processes to obtain a clad material:

- Clad plates produced by rolling which are mostly only available in standardized dimensions and grades

- Explosion clad plates

- Clad plates made by welding

Further Clad Plates made by welding can be done using various techniques:-

- $\quad$ Submerged arc welding (Wire electrode)

- Submerged arc welding (Twin Wire electrode)

- Submerged arc welding (Strip Electrode)

- $\quad$ Electro slag strip welding 
- $\quad$ Shielded metal arc welding

- Flux cored arc welding

Among all the welding processes submerged arc and electro slag strip cladding offer maximum deposition rate, better bead characteristics and trouble free operation using unsophisticated welding equipments[6,7].

In selecting a particular weld overlay and cladding system, the following criteria may need to be considered: Deposit rate $(\mathrm{kg} / \mathrm{hr})$, productivity hardness, corrosion resistance, availability of consumables with the required metallurgical and mechanical properties, welding techniques, Quality of weld $\&$ automation technologies.

\section{PROCESS DESCRIPTION}

The electro slag strip cladding is a technique, in which a strip electrode is continuously fed into a shallow layer of electrically conductive flux. The heat required to melt the strip, the slag forming flux and the surface layer of the base metal is generated by resistance heating due to the welding current flowing through the molten conductive slag. In relation to the submerged arc strip cladding, the penetration and hence the dilution are reduced in electro slag strip cladding because the absence of arc, typical dilution levels lying between $\sim 10 \%$ [4]. The use of a conductive slag and resistance heating instead of an electric arc permits higher current densities to be used in ESSC without increasing penetration. Thus deposition rates higher than that possible with SASC can be achieved in ESSC without increasing the degree of dilution[2,3,4].

The flux used in ESSC contains, in addition to oxides like Titanium oxide and iron oxide. A large quantity fluoride of Calcium and Sodium in order to achieve the required electrical conductivity. The high Calcium fluoride content in the flux has been shown to decrease dilution level and also reduce the oxygen content in the deposited cladding to a level which is just one third compared to submerged arc surfacing. Furthermore the solidification rate of the electroslag weld metal is lower, facilitating the escape of gases and the rise of slag particles to the surface. This reduces porosity and inclusion content $[2,3,8]$.

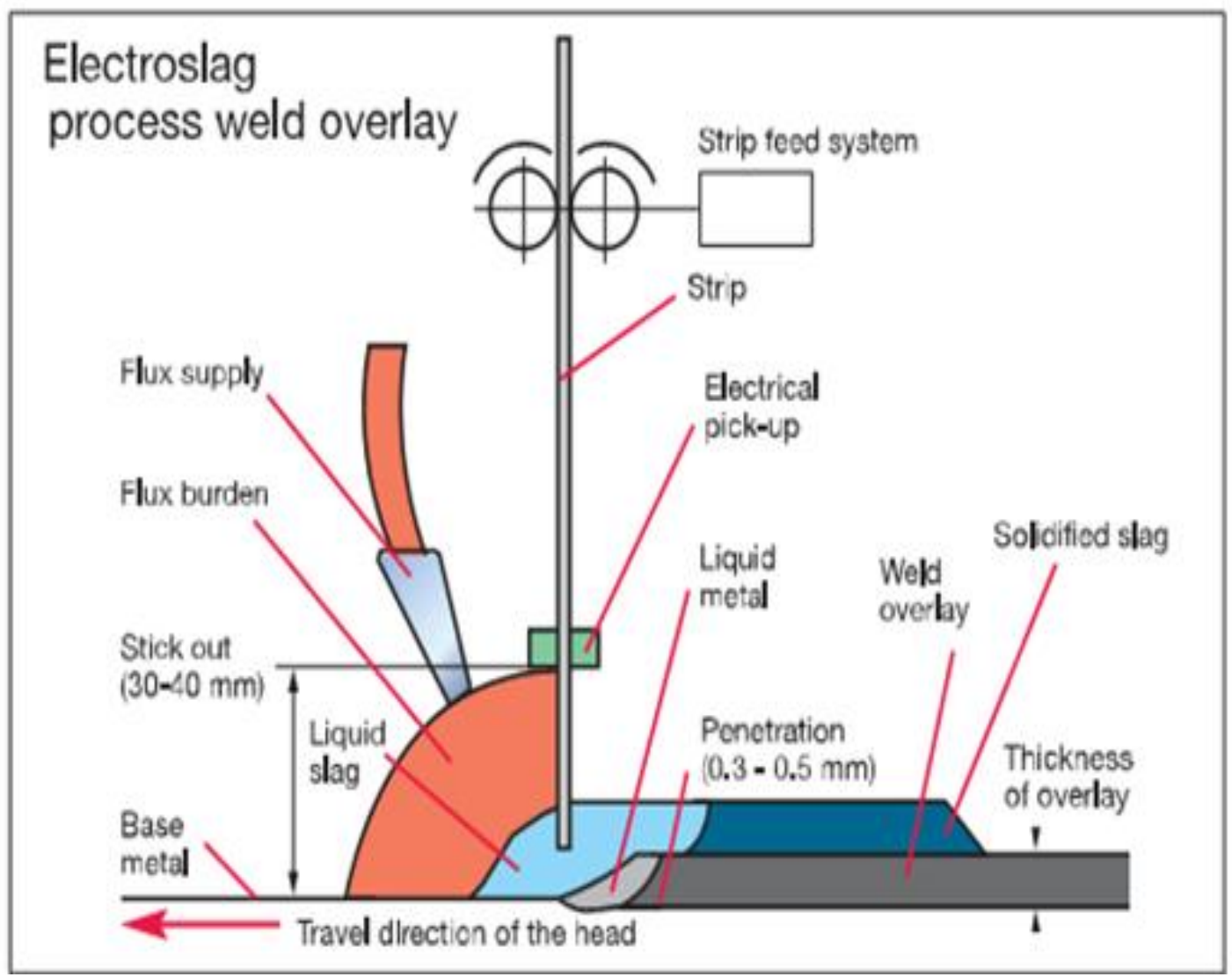

Fig.3

\section{EXPERIMENTATION AND TESTING}

Discuss the detail about the experimental data, base metal, filler metal, and welding procedure, welding parameters of welded specimen and testing. 


\subsection{Experimentation was conducted as per following flow chart}

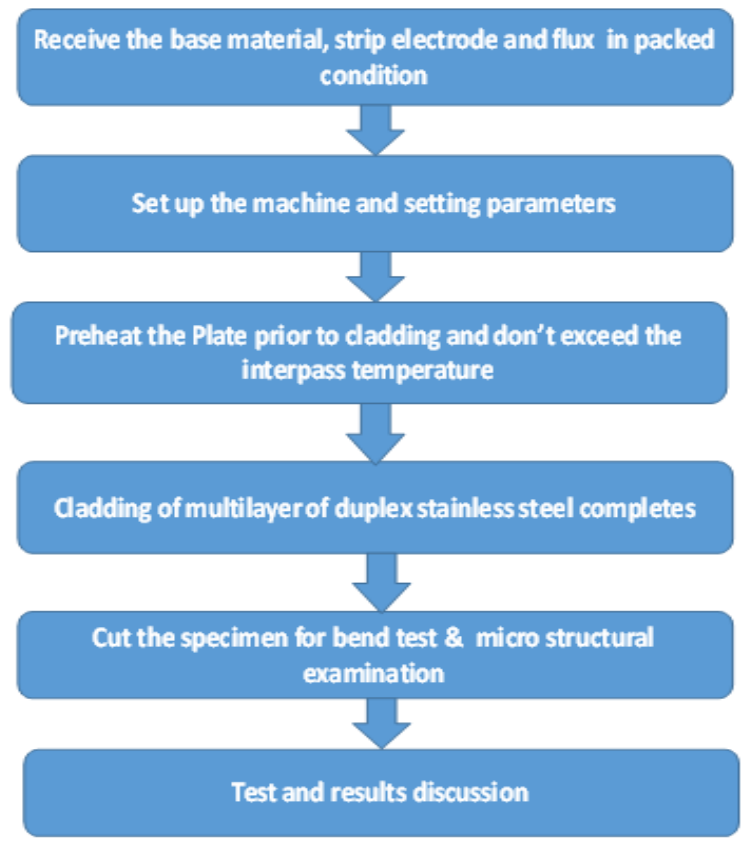

Flow chart shows how experimentation was conducted

\subsection{Base Metal and Strip Metal}

The base plate of SA 516 Grade 70 low carbon steel of $60 \mathrm{~mm}$ received in normalized heat treated condition. The strips used were of S.S
309LMo as a buffer lyer and Duplex 2209 as a clad layer .Table 3.1 shows the chemical composition of base metal \& strips used.

\begin{tabular}{|l|l|l|l|}
\hline Elements & Base Metal & SS 309 LMo & Duplex 2209 \\
\hline Carbon, C & 0.27 & 0.04 & 0.04 \\
\hline Silicon, Si & $0.15-0.40$ & 1.0 & 1.0 \\
\hline Sulfur, S & 0.035 & 0.03 & 0.03 \\
\hline Phosphorous, P & 0.035 & 0.04 & 0.04 \\
\hline Manganese & $0.85-1.20$ & $0.5-2.5$ & $0.5-2.0$ \\
\hline Chromium & - & $22-25$ & $22-24$ \\
\hline Nickel & - & $12-14$ & $8.5-10.5$ \\
\hline Molybdenum & - & $2-3$ & $2.5-3.5$ \\
\hline
\end{tabular}

Table 2

\subsection{Welding Parameters}

Material thickness : $60 \mathrm{~mm}$

Plate size : 500 X 300 X 60 mm thick

Joint design : weld overlay on CS base plate

Strip for barrier : Sandvik 21.13.3L ( EQ
309LMo)

Strip for Clad : Sandvik 22.8.3L ( EQ 2209)

Flux : Sandvik 37S

Weld Bead Height : 9-10 mm- Double Layer

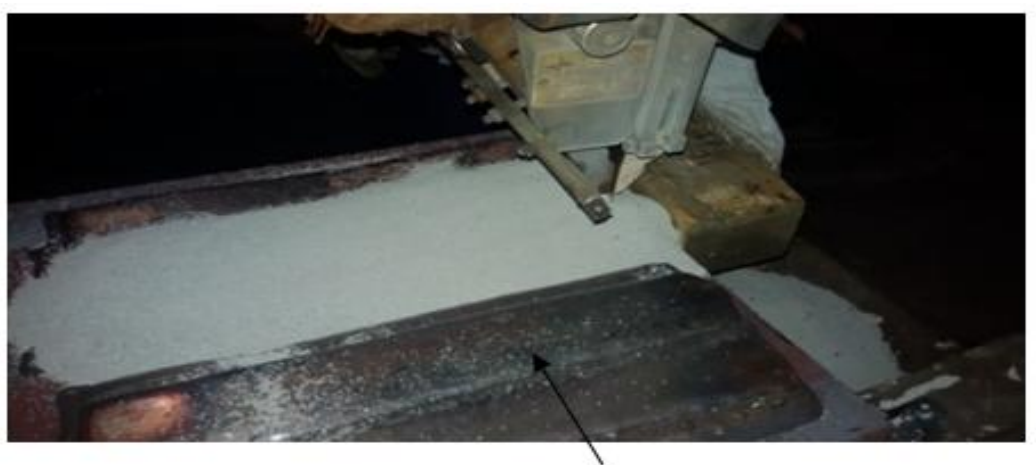


Fig.3 Barrier Layer

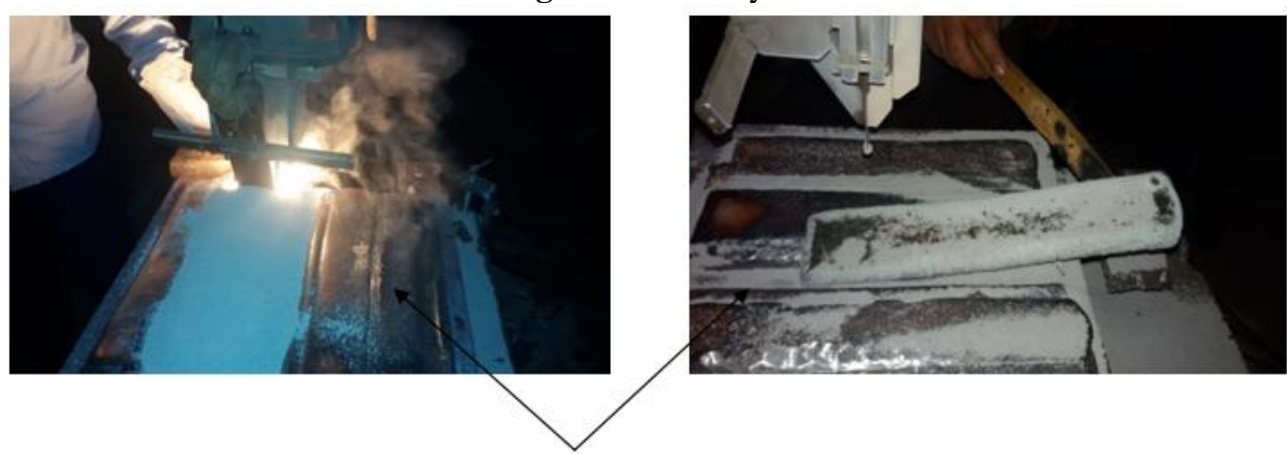

Fig.4 Clad Layer

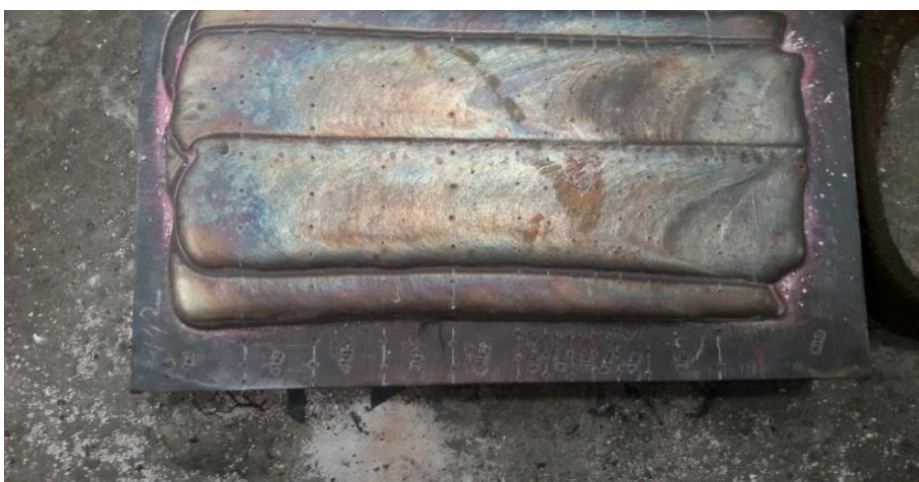

Fig.5 Specimen Marking \& Prepartion

\begin{tabular}{|l|l|}
\hline Parameters & Range \\
\hline Welding current (I) & $1150-1300 \mathrm{~A}$ \\
\hline Voltage (V) & $24-26 \mathrm{~V}$ \\
\hline Travel Speed & $170-180 \mathrm{~mm} / \mathrm{min}$ \\
\hline Pre heat & 100 degree Celsius \\
\hline Interpass & Max 175 \\
\hline Electrode extension (Stick Out) & $25-30 \mathrm{~mm}$ \\
\hline Height of Flux & $30-35 \mathrm{~mm}$ \\
\hline Polarity & DCEP \\
\hline
\end{tabular}

Table 3

\subsection{Post Weld Heat Treatment (PWHT)}

PWHT was performed at $610-620^{\circ} \mathrm{C}$ for 135 minutes after completion of testing with heating rate $50^{\circ} \mathrm{C} / \mathrm{hr}$ and cooling rate $40^{\circ} \mathrm{C} / \mathrm{hr}$.

\section{RESULTS}

$\checkmark \quad$ Visual Examination: Bead Finish- Good

$\checkmark \quad$ Non Destructive Testing

- Dye Penetrant Testing : Acceptable as per ASME Sec IX

- Ultrasonic Examination : Satisfactory

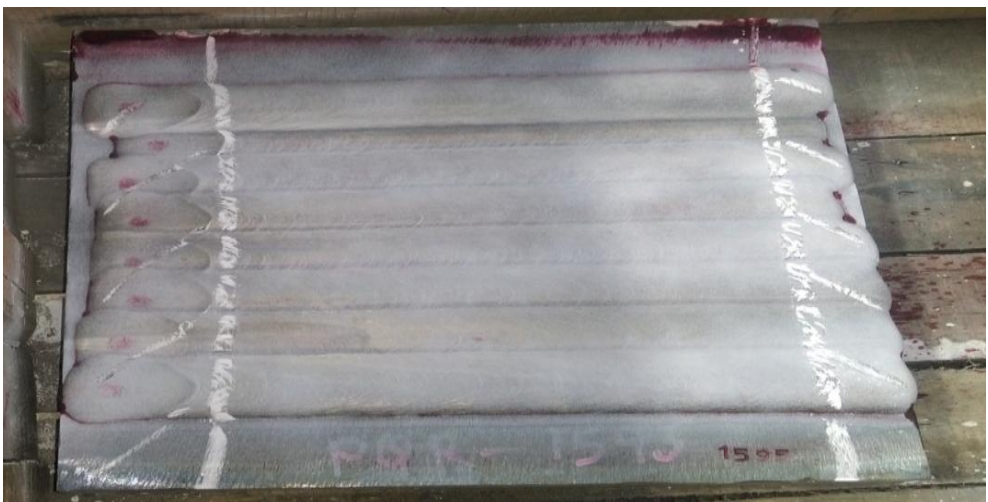


Fig.6

$\checkmark \quad$ Macro Examination : No porosity, No Lack of Fusion \& complete fusion of weld metal \& base metal

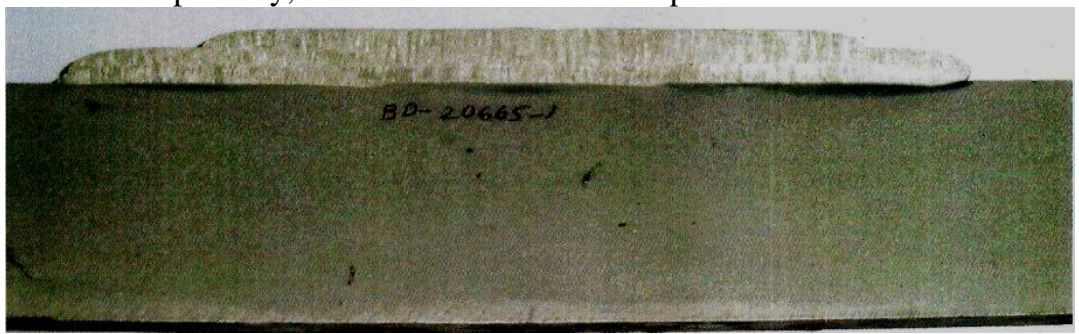

Fig.7

$\checkmark \quad$ Bend Test : satisfactory

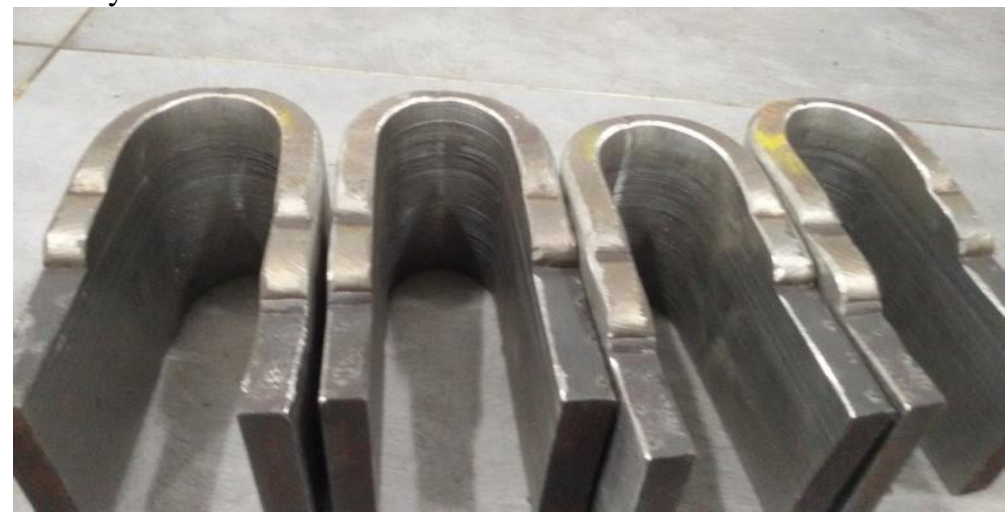

Fig.8

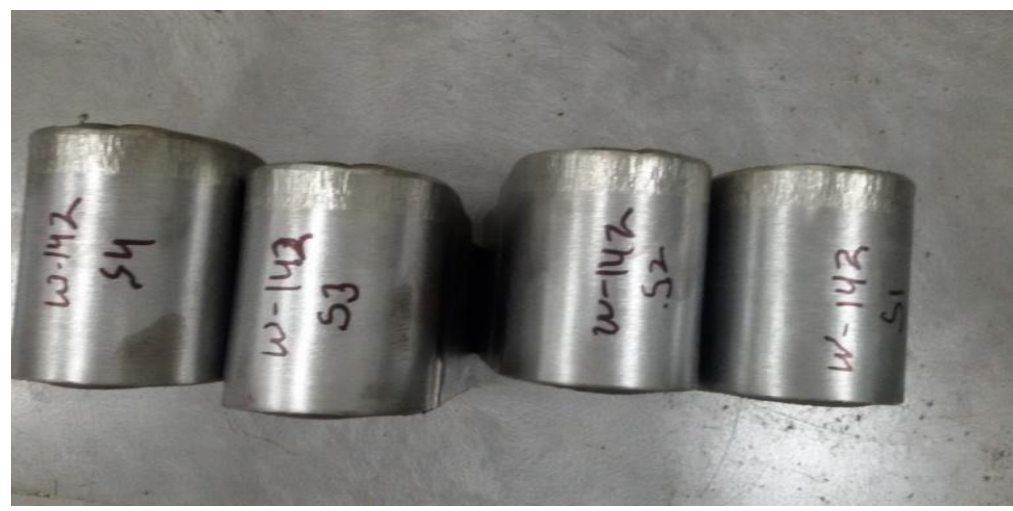

Fig.9

\begin{tabular}{|l|l|l|l|l|}
\hline $\begin{array}{l}\text { Test } \\
\text { Performed }\end{array}$ & $\begin{array}{l}\text { Number of } \\
\text { Sample Tested }\end{array}$ & $\begin{array}{l}\text { Degree of } \\
\text { Bend }\end{array}$ & $\begin{array}{l}\text { Acceptance } \\
\text { Standard }\end{array}$ & Results \\
\hline Side Bend Test & 4 & $180^{0}$ & ASME Sec IX & Satisfactory \\
\hline
\end{tabular}

$\checkmark \quad$ Chemical Composition was found satisfactory from $4 \mathrm{~mm}$ fusion line

\begin{tabular}{|c|c|c|c|c|c|c|}
\hline \multirow{2}{*}{$\begin{array}{l}\text { Height } \\
(\mathbf{m m})\end{array}$} & \multicolumn{6}{|c|}{ \% Element } \\
\hline & $\mathrm{C}$ & $\mathrm{Ni}$ & $\mathrm{Cr}$ & Mo & $\mathrm{Mn}$ & $\mathrm{N}$ \\
\hline $\begin{array}{l}\text { Reqd } \\
\text { value }\end{array}$ & 0.04 Max & $8.5-10.5$ & $22-24$ & $2.5-3.5$ & $0.5-2.0$ & $0.08-0.20$ \\
\hline Top & 0.016 & 8.70 & 22.57 & 3.05 & 1.16 & 0.16 \\
\hline 8.0 & 0.019 & 9.02 & 22.32 & 3.06 & 1.19 & 0.16 \\
\hline 7.0 & 0.018 & 9.34 & 22.08 & 3.04 & 1.18 & 0.15 \\
\hline 6.0 & 0.020 & 9.31 & 21.83 & 3.03 & 1.23 & 0.14 \\
\hline 5.0 & 0.018 & 9.30 & 21.75 & 3.07 & 1.18 & 0.14 \\
\hline 4.0 & 0.019 & 9.39 & 21.70 & 3.03 & 1.22 & 0.14 \\
\hline 3.0 & 0.040 & $* 12.17$ & *16.55 & $* 2.41$ & 1.32 & 0.011 \\
\hline
\end{tabular}

\footnotetext{
CORROSION TESTING AS PER ASTM 923 METHOD C
} 
Result observed: satisfactory

\section{Acceptance criteria}

The corrosion rate is calculated in accordance with the weight loss $\&$ it should be less than $10 \mathrm{mdd}$ ( milligrams per square decimeter per day)

Initial weight of specimen : 43.161g

Weight after 24 hours $\quad: 43.1603 \mathrm{~g}$

Weight loss : $0.0007 \mathrm{~g}(0.70 \mathrm{mg})$

Corrosion rate $\quad: 2.2150$ mdd (acceptable)

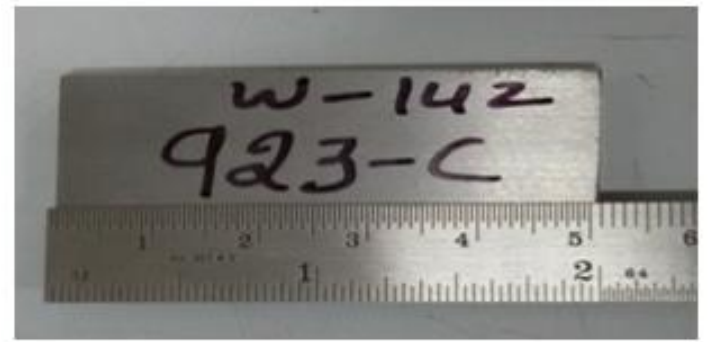

Fig.10 Corrosion Specimen (ASTM 923 METHOD C)

\section{CONCLUSION}

Typical to weld Duplex 2209 welded successfully meeting the requirement of ASME Sec IX \& Sec IIC.

\section{SCOPE OF FUTURE WORK}

As a future work, we will establish corrosion test as per customer requirement such as ASTM G-48 method A-pitting corrosion \& method B -Crevice Corrosion, ASTM G-36 etc.

\section{REFERENCES}

[1] E. M. Sherif , " Corrosion of Duplex Stainless Steel Alloy 2209 in Acidic and Neutral Chloride solutions and its passivation by Ruthenium as an alloying element."International journal of electrochemical Science 7 (2012)

[2] S. D. Kahar ," Corrosion Behavior of Electro Slag Strip Cladding Weld Overlays in Different Acid Solutions ", Int. Journal of Engineering Research and applications Vol. 3, Issue 4,july-aug 2013 pp.590-595, 2012

[3] M. Patel," Application of Electro Slag Strip Cladding for reactors in Hydrogen Based Refinery"2009-IIW india

[4] A.Eghlimi "dilution and ferrite number prediction in pulsed current cladding of super duplex stainless steel using RSM" ASM international (2013).

[5] T. Kannan: "effect of flux cored arc welding process parameters on duplex stainless steel clad quality". Journal of materials processing technology 176(2006).
[6] R.A Daemen: submerged arc stainless steel strip cladding: the development of welding products for surfacing with a type of $316 \mathrm{~L}$ low ferrite stainless steel alloy. Welding Research supplement January-1970.

[7] S.Pak "Electro slag and Submerged Arc stainless steel strip cladding."published by ESAB in Svetsaren No.3,1996

[8] J. Garg, "reuse of slag in stainless steel cladding and its effect on chemistry of cladding in SAW process"Journal of Environmental research \& Development(March 2012). 